\title{
Rereading Empire, Rethinking History: Rehabilitation of the Vietcong in Lan Cao's Monkey Bridge
}

\section{Yuan Shu}

Texas Tech University, USA

\begin{abstract}
Through its reading of Lan Cao's Monkey Bridge, credited as the first Vietnamese American novel, this article seeks to investigate the discourse of reconciliation or refugee settlement in the context of the changing US master narratives from Empire to Cold War 2.0. It argues that Cao's novel in its effort to register a South Vietnamese perspective reorients modern Vietnamese experiences in relation to the US sense of democracy and freedom and in the process challenges what Donald Pease calls the state fantasy of American exceptionalism in the US military intervention in Vietnam. What Cao's novel achieves is to blur the boundary between nationalism and communism in its representation of the Vietnamese struggle for independence in its early stage and to humanize and rehabilitate the Vietcong soldier as a possibly assimilable "us" rather than as simply "them" in the realm of the other.
\end{abstract}

Keywords: Monkey Bridge, Vietnam War, Cold War, Vietnamese American literature, reconciliation narrative

With the flourishing of Vietnamese American literature in recent years, which culminated in the publication of Viet Thanh Nguyen's debut novel, The Sympathizer, and its being awarded the 2016 Pulitzer Prize for Fiction, Asian American studies has also witnessed new critical vitality and intellectual creativity. Not only have critical refugee studies and war ecology analyses animated the field imaginary, but they have also transformed the studies of Vietnam War literature and culture. Revisiting the ethics of war, the aesthetics of cultural production, and the global culture industry, this new generation of Asian American studies scholars have expanded a US-based Vietnam War literature into the phenomenon of what I call a global Vietnam War literature and culture.

Indeed, in his innovative scholarly work, Nothing Ever Dies, Viet Thanh Nguyen engages different dimensions of cultural memory of the Vietnam War or rather the American War in Vietnam beyond print culture and explores new forms and new modes of representation that point to the hierarchy of the memory industry and its underlying power structures. With new attention to museums, monuments, and historical sites in North America and the Asia Pacific as memories and postmemories of the war, Nguyen highlights the paradox that the United States lost the war in Vietnam but has won the battle of cultural memory in the US and around the globe. 


\section{SARE, Vol. 58, Issue 2 | 2021}

What he strives to achieve is not an alternative way to reconsider the US-centered and industry-driven cultural memory of the war but a new discourse that would scrutinize the politics of remembering and forgetting, the complexity of humanity and inhumanity, and the permeability between victimization and perpetration in terms of ethics, aesthetics, and economics.

If Nguyen's new critical model enables us to think beyond the dichotomy of us versus them and to critique the inhumanity arising from all sides including the atrocities perpetrated by the Vietnamese against Cambodians or Cambodians and Laotians against themselves and each other, then how should we critically reflect upon the Vietnamese American perspectives on the war in relation to the US culture industry? How do we factor in the changing and improving relations between the US and Vietnam and the geopolitics of the transpacific in our interpretation of Vietnamese American literature? In this essay, in reading Lan Cao's Monkey Bridge, which has been credited as the first Vietnamese American novel, I seek to investigate the discourse of reconciliation or refugee settlement in the context of the changing US master narratives from Empire to Cold War 2.0. I argue that Cao's novel, in its effort to register a South Vietnamese perspective, reorients modern Vietnamese experiences in relation to the US senses of democracy and freedom and in the process challenges what Donald Pease calls the state fantasy of American exceptionalism in the US military intervention in Vietnam. What Cao achieves here is to blur the boundary between nationalism and communism in her representation of the Vietnamese struggle for independence in its early stage and to humanize and rehabilitate the Vietcong soldier as a possibly assimilable "us" rather than as simply "them" in the realm of the other.

\section{Reconsidering Vietnamese American Literature in the Changing Context of the US-centered Global Order: From Empire to Cold War 2.0}

As arguably the first Vietnamese American novel published in 1997, Lan Cao's Monkey Bridge should be contextualized in the historical juncture of what Francis Fukuyama problematically calls "the end of history," which in the neoliberal sense serves as "a single, coherent, evolutionary process, when taking into account the experience of all peoples in all times" (Fukuyama xii). This notion of a so-called "universal history" has been best captured by Michael Hardt and Antonio Negri's concept of Empire, a new global order which aims to theorize the collapse of the Soviet Empire and the shift of the responsibility of the US military momentarily from its global fight against Communism to a new global mission in peace-keeping under the Clinton administration in the early 1990s. In their modification of the Westphalian principles of sovereignty and balance of power, and by redefining 


\section{SARE, Vol. 58, Issue 2 | 2021}

US Cold War military structures and capabilities, the two authors retool the United States from the sole superpower to a network power in the Roman tradition of imperial right:

The concept of Empire is presented as a global concern under the direction of a single conductor, a unitary power that maintains the social peace and produces ethical truths. And in order to achieve these ends, the single power is given the necessary force to conduct, when necessary, "just wars" at the borders against the barbarians and internally against the rebellious. (Hardt and Negri 10)

Hardt and Negri make a specific distinction between "just wars" and the Vietnam War in that the latter might be considered as "the final moment of the imperialist tendency and thus a point of passage to a new regime of the Constitution" (178). In other words, Empire in essence is "the global expansion of the internal U.S. constitutional project" (182). But this neoliberal fantasy of Empire was totally shattered by the War on Terror started by the George W. Bush administration in 2003 and only ended recently by the Biden administration in 2021. Since the Obama administration announced the US pivot back to Asia in 2011, Vietnam has started playing a new role in the US-centered global order, particularly with regard to its maritime disputes with China. In July 2013, Presidents Obama and Sang launched the US-Vietnam Comprehensive Partnership, an overarching framework for cultivating and developing their bilateral relationship. When Secretary of Defense Ashton Carter announced the progress of the US pivot to Asia at the McCain Institute in 2015, he showcased an improving US-Vietnam relationship by bringing together Senator John McCain, a former POW of North Vietnam, and Vietnam's Ambassador to the US, Pham Quang Vinh, as a gesture of reconciliation and to foster a spirit of collaboration. If the Cold War ended in Europe in 1991, the United States has never disassembled or downgraded the two pillars of its Cold War regional security structure in the Asia Pacific, which encompasses the hub-and-spoke system of bilateral military alliances and forward-deployed military capabilities (Twining 79). On the contrary, these structures and installations have been reinforced and expanded. As illustrated by the 1996 Japan-US Joint Declaration on Security, ${ }^{1}$ and reconfirmed in Secretary Hillary Clinton's 2011 essay, "America's Pacific Century" (57), the US has consolidated bilateral military alliances with its Cold War allies of Japan, South Korea, Australia, New Zealand, Singapore, the Philippines, and Thailand on the one hand, and cultivated new partnerships with other regional powers such as India, Vietnam, Indonesia, and Malaysia on the other hand.

In his article, "Beyond Port Visits, US-Vietnam Relations Can Go Further," in The Diplomat on March 27, 2020, Mathew Dalton, Lieutenant Commander of the US Navy and Federal Executive Fellow at the Chicago 


\section{SARE, Vol. 58, Issue 2 | 2021}

Council on Global Affairs, celebrates the significant progress made by the two countries from being enemies during the Vietnam War to forging a comprehensive partnership in recent years: "Political and economic components have played key roles in the ongoing normalization of affairs, but so too has the military. As Vietnam seeks to hedge against China's growing influence in the region, now is the time for the United States and Vietnam to push their relationship to a new frontier." As he believes there is ample room to expand the burgeoning USVietnam relationship, Dalton argues that the US needs to come to the negotiating table with a new package that would provide Vietnam with enhanced trade and economic benefits.

In this changing scenario of the geopolitics of the transpacific, Lan Cao's novel should be read as something beyond what Viet Thanh Nguyen calls the "reconciliation narrative" $(2002,107)$, and instead examined in a new light that would enable us to rethink the US military intervention in Vietnam as part of the US-centered global order. Moreover, Cao's effort in presenting a South Vietnamese perspective becomes more important today precisely because the former US ally has been represented as corrupt, incompetent, and deserving of the final defeat.

\section{Remediating Empire: Colonialism, Nationalism, and the Declaration of Independence}

In an NPR report in September 2019, Lan Cao reiterates the importance of including more perspectives on the war in the sense that Vietnam has become a syndrome warping the American worldview: "It's reproduced itself into a template for how American foreign policy and discussions of American foreign policy seem to revolve around, which is a very U.S.-centric direction" (O’Driscoll). She argues that the US should know the other countries it is dealing with and be aware that they are not just the background, a warning that seems particularly important at a moment when the US has dramatically improved US-Vietnam relations.

When asked specifically about her inspiration to write Monkey Bridge, Lan Cao expressed her concern on a lack of Vietnamese perspectives in the representation of the Vietnam conflict in American popular culture: "I saw Vietnam as a country that was thoroughly defined by the U.S. as no more than a war. Even as a war, only one segment of the story was being told - that of the U.S. The Vietnamese side, whether from the North or South, remained unheard" (Ettenheim). She articulates her intervention in the representation of the Vietnam War in terms of intellectual desire and at the level of personal experiences:

Having said that, I should add that although the desire to add another side to the story was certainly part of what motivated me to write, that desire was more or less an intellectual desire only. It wasn't until my mother herself fell ill that I felt compelled 


\section{SARE, Vol. 58, Issue 2 | 2021}

on a personal level to write a story about the relationship between a mother and daughter as they learned to cope with each other and each other's experience in the aftermath of war. (Ettenheim 1)

As the perspective of the South Vietnamese has never been represented in US Vietnam War literature, how would Cao negotiate and assimilate the former US ally into American culture and society? Ultimately, if her desire is to bridge the gap between Vietnam and the United States as the title of her novel suggests, then how would she represent the Vietcong as the common enemy of South Vietnam and the US?

Set in Falls Church, Virginia during the 1980s, Cao's Monkey Bridge revolves around the journey of a young Vietnamese American woman, Mai Nguyen, who, before entering college and adulthood, seeks to find out the "truth" about her family history and come to terms with the impact of the war upon herself and her family. What Mai pursues specifically in this scenario is an explanation of why her grandfather failed to show up at the rendezvous place in Saigon to meet her mother and be evacuated on 30 April 1975. As Mai looks for more information and pieces together more evidence, she finds with horror that her beloved grandfather was actually a Vietcong insurgent, even though he had been honoured by both the South Vietnamese government and the US military during the war for having bravely saved the lives of US soldiers in a Special Force unit. In reconstructing her grandfather as a Vietcong soldier in the domestic space of the extended Vietnamese American family, Mai finally realizes that the "enemy" could have been somebody like "us" if not living with "us."

Cao begins her reinvention of the Vietcong by offering a different interpretation of the Vietnamese Communist mastermind Ho Chi Minh and the political cause that he had represented for Vietnam during the war. Through the narrative viewpoint of Mai's deceased father, Binh, a member of what Cao describes as the Third Force in South Vietnam during the war, she depicts Ho Chi Minh as a political idealist who had been inspired by the American Revolution, particularly the Declaration of Independence. Based partially on historical documents and partially on creative imagination, Cao elaborates on how Ho Chi Minh declared the independence of "the Democratic Republic of Vietnam" from the French in Hanoi in September1945 by inviting US Army officers to witness the historical event and arranging for a Vietnamese band to play the US national anthem, "The StarSpangled Banner," as the highlight of the ceremony. Describing Ho as an admirer of American democracy, who could quote directly from the Declaration of Independence, Cao redefines this historical event as "the one signal, the only signal the Americans should have needed to make the obvious and right response" (Cao 26), a response which "would have made the difference between peace and war, life and death" (26). Cao questions the confusing decision made by the US government, which had betrayed the political tradition and the democratic principle of 


\section{SARE, Vol. 58, Issue 2 | 2021}

the American Revolution. This critique produces what Michele Janette calls a "guerrilla irony," which measures US political idealism against its global practice in the Asia Pacific and downplays the difference between the First World and the Third World. But this is precisely the point that Cao wants to question about the universality of American political idealism.

As Cao rewrites history as contingency, she emphasizes further that Ho Chi Minh did more than just stage a public show of his admiration for American democracy, and that he also repeatedly contacted the US government for diplomatic recognition and political assistance. During Ho's involvement in the resistance movement against the Japanese occupation in the early 1940s, the narrator documents that he wrote several letters to President Truman and his successors, pleading with the US government to recognize his newly established but yet to be acknowledged provisional government. Had President Truman responded to the request of Ho Chi Minh, the narrator's father, Binh, speculated with regret, sorrow, and a sense of helplessness, then the whole course of modern Vietnamese history would have been rewritten and Vietnam would never have got into the nightmare of an endless war that involved the United States, the Soviet Union, and China. He ended with a provocative question, "Who could have thought that a country that fought for its independence from Great Britain would side with the French empire?" ( Cao 26).

Through Binh's innocent questioning of the US support of the French in Vietnam as inconsistency in logical reasoning, Cao foregrounds the discrepancy between the theory and practice of the US government, which would point to what Amy Kaplan calls "the ideological cornerstone of U.S. imperialism and a key component of American exceptionalism" (3). In other words, the framing of the question highlights the historical context in which the United States was trying to assert its global hegemony and create a new global order in the wake of the crumbling of European colonial rule and the flourishing of decolonization movements in Third World countries after World War II. Using the United Nations as a political platform and Third World countries as their theater for military confrontation, the United States and the former Soviet Union competed and contested their political and military powers for a new global order. To prevent the former European colonies from falling into the Soviet Communist camp, the United States had to do whatever necessary, including soliciting support from the European colonial powers and sustaining pro-American but often corrupt Third World governments against the possible emergence of Communist regimes. In the context of Vietnam, as the United States strived to envision and develop its new global order against Soviet Communism, it could not have had any empathy for what Hardt and Negri call "the barbarians and the rebellious slaves" of the old global order defined by the European colonial powers (20), but instead sided with the French colonial power in order to root out subversive elements that could lead to 


\section{SARE, Vol. 58, Issue 2 | 2021}

a new Communist regime. Ironically, the "democratic" state envisioned by the United States and other allied forces for the Third World at this moment was no more than what historian Patricia Pelley defines as "nonCommunist, pro-Western, and dependent" (2). In presenting the problem as unfathomable in terms of logical reasoning, Cao implicitly suggests that the United States had switched its position from one end of the spectrum, which voiced anti-colonial democracy and freedom during the American Revolutionary period, to the other end, which identified with the French colonial power in Vietnam. This is despite the fact that the American Revolution itself was far too complicated to simply be swept under the general rubric of "anti-colonialism" rather than settler colonialism, a practice that would continue to render the North American indigenous population invisible and irrelevant.

Moreover, the provocative question also raises the issue of how we understand the political and historical circumstances in which Ho Chi Minh pronounced the Vietnamese declaration of independence from the French. When Ho invited the US Army officers for the important occasion and quoted explicitly from the American Declaration of Independence, he sought to consolidate the historical event by soliciting recognition and support from the United States, which had been and would continue to be the most powerful nation-state around the globe and the banner for the entire "free world." In fact, in the second paragraph in the original Vietnamese document, right after quoting the famous statement from the Declaration of Independence, Ho contested its universal validity by applying and appropriating its meaning for all peoples of Third World countries: "Understood in the broader sense, this means: 'All peoples on the earth are born equal; every person has the right to live to be happy and free"" ("Declaration" 28). What Ho offered here was a provocative appropriation of the American Declaration of Independence, which would extend to peoples of all nations and include people of all colors without any presupposition. To reinforce his appropriation, Ho also proceeded to quote from the French Declaration of Human and Civic Rights declared during the French Revolution of 1789, and denounced the French violation of the rights of the Vietnamese in both the political and economic realms, exposing the hypocritical and incompetent nature of the French colonial authorities, which had surrendered to the Japanese aggressors and provided no protection for the Vietnamese people as promised before World War II. In his conclusion, Ho announced the determination of the Vietnamese people to fight for their freedom and independence: "The People of Viet Nam decide to mobilize all their spiritual and material forces and to sacrifice their lives and property in order to safeguard their right of Liberty and Independence" (30).

The political manifesto of Ho Chi Minh in this light mimicked and performed the American Declaration of Independence as a matter of convenience, which would test the universality of American political values in its 


\section{SARE, Vol. 58, Issue 2 | 2021}

solicitation of US support, but which could not bridge the gap between the two nations in politics, history, economy, and culture. In other words, the appropriation of the American Declaration of Independence for the Vietnamese people at this historical juncture could only function as a mimicry that sought legitimacy in a way similar to what Homi Bhabha theorizes as the "representation of a difference that is itself a process of disavowal" in the colonial Indian context (86). As a sign of double articulation, Bhabha argues, mimicry serves as "a complex strategy of reform, regulation and discipline, which 'appropriates' the Other as it visualizes power" (86). Indeed, even though France rather than the United States represented the colonial power in Vietnam at this point, Ho appropriated the American sense of democracy and the French notion of human rights for the Vietnamese. On the one hand, while performing and repeating the Declaration of Independence in French Indochina, Ho affirmed the universal values of "life, liberty and the pursuit of happiness" in order to prevent the French from regaining their colonial power over Vietnam, which had been lost to the Japanese military during World War II. Of course, Ho consolidated an imaginary of the three loosely related regions of Tonkin, Annam, and Cochin China into a Vietnamese nation-state. On the other hand, precisely because neither the French nor the US governments could endorse or respond to this Vietnamese political imaginary, Ho's political manifesto could only function as political mimicry and parody, which would question the ubiquity and validity of American democratic values in the colonial Vietnamese context. Such mimicry and parody were even more ironic when the United States itself got involved in the war, and escalated it on a grand scale two decades later. In this light, mimicry is precisely what Bhabha calls "the sign of the inappropriate" in the sense that its difference or rather recalcitrance coheres "the dominant strategic function of colonial power, intensifies surveillance, and poses an imminent threat to both 'normalized' knowledges and disciplinary powers" (86). In a word, though mimicry was ineffective as a discourse to the French colonial power, it nevertheless contested the consistency of the American democracy in a colonial context and mobilized the Vietnamese peasants against all Western powers.

Through the character of Mai in the novel, Cao pursues the mistake of the US government in terms of the Vietnamese expression of "one wrong move," which Mai describes as "something of an incantation in our house" as well as being infused "with all the apocalyptic forces of history" (Cao 26). Mai defines the "one wrong move" this way:

To commit "one wrong move" was to invite catastrophe, to go against an irresistible movement, to be on the wrong side of a metaphor. To be guilty of "one wrong move" was to be caught in the web of history, the way my family and other Southerners found themselves, in the Southern half of the country, reinforced by the United States 


\section{SARE, Vol. 58, Issue 2 | 2021}

in a war against the Northern half, led by Ho Chi Minh and supported by the Soviets and the Chinese. (26-27)

As this "one wrong move" was determined historically by the nature of the US military intervention at the moment, it would produce serious consequences for Vietnam and the Vietnamese people. Precisely because a Third World country such as Vietnam could not articulate its own desire or interest in the old European imperial world order or in the new global order envisioned and pursued by the United States, Vietnam had to be arbitrarily divided into the North and the South along the seventeenth parallel by the competing superpowers, which would turn it into a theater of violence and brutality, taking away thousands of lives of the Vietnamese and of other Southeast Asians and destroying the ecological balance and systems of the entire region.

\section{"US" versus "THEM": Class Struggle and the Rehabilitation of the Vietcong}

If the contradiction of the US government is perceived as "one wrong move" rather than as a constant in the process of empire building, then the similarity between the Vietcong and American Revolutionary soldiers depicted in the novel functions as what Shu-mei Shih calls "belated sameness," by which she designates the "technology of recognition" for the First World readership to confirm the validity of their own values in the consumption of Third World cultures and societies (25). As Cao constantly switches the setting between colonial Vietnam and multicultural America, she describes her own politics of representation through the character of Mai: "stereotypes are not my enemy, as long as we tinker with them in a way that strikes an American chord" (Cao 147). In this light, the similarity between American militiamen during the Revolutionary Era and the Vietcong soldiers during the Vietnam conflict is not situated in any specific historical context but revolves around the absoluteness of Empire which encompasses all spatial and temporal totalities.

In "tinkering with stereotypes," Cao also creates a new dimension to the meaning of "difference," which she calls "acceptable difference" (147) and by which she means something assimilative to the dominant culture. In resituating Mai's grandfather as a Vietcong soldier in a space between the Vietnamese American family of "us" and the Vietnamese peasant society of "them," Cao domesticates the Vietcong soldier for the American readership and represents Vietcong differences in two ways. First, Cao suggests that the war did not necessarily provoke any hard feeling among the Vietnamese toward Americans even though Vietnam suffered tremendous loss of human lives and properties during the war. In focusing on the conflict between the grandfather and a local wealthy landowner, Cao shifts the anti-colonial dimension of the war in Vietnam to the domestic preoccupation of class struggle, which she reconfigures as the dominant problem in Vietnamese culture and society at that time. 


\section{SARE, Vol. 58, Issue 2 | 2021}

Moreover, even though Cao's focus is primarily on the domestic class struggle, her sense of class struggle is entangled with the idea of personal revenge rather than the notion of what Georg Lukacs calls "class consciousness," which had played a central role in classic Marxist theory. In other words, class struggle in orthodox Marxism always served as a strategic objective for the Communist party to imagine its common enemy, advance its own political interest and agenda on that basis, as well as consolidate the consciousness of its working class masses (Marx 218).

In the colonial context, class struggle assumes an even more complex form in that it always foregrounds the violent nature and racial dimension of class conflicts. In The Wretched of the Earth, Frantz Fanon notes the specific function that violence had performed in what he calls "the peasant revolution" in Algeria: "the starving peasant, outside the class system, is the first among the exploited to discover that only violence pays" (61). Such violence committed by peasants, Fanon argues further, may also be important to the formation of the new consciousness of each individual peasant, which at that specific moment has to break with its own humiliating past as well as to project a new beginning and future for himself: "At the level of individuals, violence is a cleansing force. It frees the native from his inferiority complex and from his despair and inaction; it makes him fearless and restores his self-respect" (94). In theorizing violence at both the collective and individual levels in the colonial and postcolonial contexts of Algeria, Fanon suggests the strong motivation for revenge among individual peasants, which would characterize various nationalist and de-colonization movements at their specific historical junctures.

In the Vietnamese context, class struggle had to be articulated and understood in terms of an anti-colonial nationalism so that Vietnamese Communist leaders could legitimize themselves as the authentic representative of Vietnam in their competition with the South Vietnamese government, and mobilize the people effectively against the US military presence, which had already been associated with the French colonial power. As narrated by Le Ly Hayslip in her co-authored memoir, When Heaven and Earth Changed Places, Vietcong leaders achieved their leadership by preaching their political doctrine in easy and visual terms: "Freedom meant a Vietnam free of colonial domination. Independence meant one Vietnamese people — not two countries, North and Southdetermining its own destiny. Happiness meant plenty of food and an end to war" (xi-xii). Since these notions were accessible and appealing, Vietnamese peasants could easily answer the Communist call for resistance and develop their hatred of Western colonialism based on their own observation of the flourishing of "bars, brothels, black markets, and xi hoi van minh — bewildering machines — most of them destructive" after the US presence in Vietnam (xiii). As for the Vietcong soldiers, they were not only indoctrinated to believe that they had been fighting 


\section{SARE, Vol. 58, Issue 2 | 2021}

for the great cause of independence, but they were also supposed to understand their struggle as part of the international proletariat liberation movement. In the recently recovered diary of a Vietcong doctor, Dang Thuy Tram, which is entitled Last Night I Dreamed of Peace, she uses as the epigraph a quote from the popular Soviet novel, How the Steel Was Tempered, by Nikolai Ostrovsky:

A person's most valuable possession is life. We only live once; we must live so as not to sorely regret the months and years lived wastefully, not to be ashamed of the months and years lived wastefully, so that when we die we can say, 'All my life and all my strength have been dedicated to the most noble goal in life, the struggle to liberate the human race.' (Tram 18-19)

Such interpellation enabled Vietcong soldiers to endure extreme hardships and sacrifice their lives willingly for a great cause and thus stipulated a sort of religious satisfaction in the illusion that their sacrifice would contribute to the independence of Vietnam as well as the liberation of humanity.

When Cao reinvents the Vietcong in her narrative, class struggle in the classic Marxist sense yields to personal revenge in the traditional Vietnamese style, and racial violence as articulated by Fanon surrenders to class-oriented retaliation on landowners, a violence that is perpetrated by an individual in the name of the collective force of the Vietnamese peasants. This personal revenge features the contradictory nature of Mai's grandfather, Baba Quan, who as a Vietcong solider and a Vietnamese peasant had been caught in the colonial context. When Baba Quan made a decision to prostitute his wife as a concubine for a wealthy landowner and regretted it later, he could not regain his respect and dignity by simply canceling the deal with Khan, the landowner, who had been "the most powerful landowner in Ba Xuyen, with holdings so vast that, as the saying goes, a stork would have to stretch the full majestic length of its wings to fly the expanse of his land" (Cao 6). The only possible solution for him was to join the Vietcong and resort to collective power as a means to materialize and rationalize his personal revenge. But Cao does not just present the angry and humiliated Vietnamese peasant as "the other" for "us" in terms of an Orientalist sense of irrationality. She also identifies the contradictory or rather humanistic side of the grandfather with "us," a contradiction which actually allowed him to risk his own life to honor the friendship between Binh, his son-in-law, and Michael, an American Special Forces officer stationed in Saigon, and to save the lives of Michael and other American soldiers in his Special Forces unit, when they had been caught in the labyrinth of landmines planted by the Vietcong. In this sense, the "Vietcong" soldier is both similar and different, situated between "us" and "them." 


\section{SARE, Vol. 58, Issue 2 | 2021}

To make her story realistic and convincing, Cao begins her novel by describing the differences between American and Vietnamese hospitals, offering a moment of reflection upon the mystery of the narrator's grandfather, who never showed up at the rendezvous place in Saigon on 30 April 1975. The interpretation of the incident and then of the grandfather is mostly based on the accounts of Mai's mother, Thanh, who describes the grandfather, Baba Quan, as "a traditional man, a devout Confucian who did not like to travel away from his village home" (Cao 5). This impression of the grandfather is confirmed by Michael, an American officer, who had sponsored Mai to emigrate from Vietnam to the United States before the fall of Saigon in April 1975. Michael uses similar words of praise, such as "hardworking," "very strong sense of right and wrong," and "devoted to rituals and tradition" in his depiction of the seemingly harmless Vietnamese peasant (Cao 108).

As Mai sorts out her mother's letters and journals after the latter's hospitalization, she discovers with horror that her grandfather Baba Quan had actually been a Vietcong soldier, from whom her mother had tried to escape all her life. This revelation not only shocks Mai as a teenager who has bought into the stereotype in American popular culture of the Vietcong as cruel, alien, and inhuman, but it also blurs her sense of good and evil, victim and villain, "us" and "them." As she continues to read her mother's letters and journals, Mai is more surprised by the fact that her Vietcong grandfather actually killed a wealthy landowner in cold blood, and that her mother had tried to protect her by creating a different image of Baba Quan as a simple and traditional Vietnamese peasant: "Baba Quan was a devoted husband, a father dedicated to an uncomplicated life among the green terraced fields and fresh plowed earth of Ba Xuyen, a farmer who tilled the land with patience and dignity" (Cao 229).

With the unfolding of the story of Baba Quan, Mai comes to the darker side of the grandfather who was "a husband fully capable of asking his wife to prostitute herself to a rich landlord known in the Mekong Delta as Uncle Khan" (Cao 229). This dramatic turn of events raises questions concerning the historical background of Vietnam and the mentality of the Vietnamese peasant who had been caught in complex socio-political and socio-

economic circumstances. Cao uses this incident as a justification and motivation for Baba Quan to join the Vietcong forces and avenge his personal wrongs on the landlord Khan.

Through the mouth of Thanh, Cao describes the mentality of Baba Quan after the incident, a Vietnamese peasant who had been totally consumed by his own anger, shame, guilt, and desire for revenge:

That was when I realized the raw, untamed anguish of a man who had lived his life like a clenched fist, a man who had dreamed of turning a cool hatred into a tormented bowl for revenge - against a landlord who had turned his wife into a concubine and taken from him a child who should have been rightly his. (Cao 250) 


\section{SARE, Vol. 58, Issue 2 | 2021}

This hatred of the landlord finally enabled him to resort to violence and murder Khan in cold blood: Through a faint stream of light cast by a kerosene lantern, I could make out the redsmeared face of Baba Quan. While another man pinned Uncle Khan to the ground, Baba Quan plunged a knife through Uncle Khan's throat. (Cao 249)

To justify his own violence and brutality, Baba Quan readily repeated the slogan of the Vietcong and covered up his own personal revenge in the collective name of the Vietnamese people: "Let him know. Crimes against the people cannot go unpunished. Land to the landless!" (Cao 249).

In portraying the violent and ruthless Vietcong as the grandfather of the narrator as well as a traditional Vietnamese peasant, Cao describes the complex social historical context, in which the Vietcong soldiers and Vietnamese peasants were situated, and in a sense brings nationalism, anti-colonialism, and Communism to the individual level of personal gratitude or revenge. Baba Quan in this sense functions as a contradiction of personal emotion rather than an ideological product of the specific time and space:

That was what motivated him to risk his own life to save Michael from the riddles of a minefield he himself had designed. Love and hate rivered through his veins and blasted through his flesh, and he could as easily murder his enemy, the landlord Khan, as he could save an American Special Forces unit. (Cao 251-52)

Cao repositions the Vietcong in the marketplace of the United States, which consumes the reconciliation narrative but may not want to go through the complicated social, political, and historical context that has produced those tragedies. On the one hand, in showing that a Vietcong could be somebody like the narrator's grandfather and could save the lives of American soldiers at the same time, Cao suggests to the American readership that the Vietcong was as humane and complex as any of "us" within Empire. But on the other hand, as she demonstrates that the same Vietcong could prostitute his own wife and murder people in cold blood, Cao also frames the grandfather in the category of "the other," whose behavior, mentality, and rationality were beyond the comprehension of "us" as American readers. In a sense, she reinvents the familiar Vietcong with a difference to undermine the assimilating power of the global market. 


\section{SARE, Vol. 58, Issue 2 | 2021}

\section{Alternative within Empire: Reconciliation, Multiculturalism, and the Global Market}

In reinventing the Vietcong with both similarity and difference, Cao rehabilitates Vietnam for the US readership as a site of "reconciliation" that both engages multiculturalism in the domestic context and responds to late capitalism in the global context. Cao's narrative does not constitute an alternative to Empire but rather provides an alternative within Empire, a phrase invented by Hardt and Negri to designate a new sense of identity, which has been "imposed on the constitution of Empire by the creative movement of the multitude," and which pushes "the dominating power toward an abstract and empty unification" (62). But such an alternative within Empire foregrounds the contradiction between the gesture to critique Empire and the interest to participate in its practice.

Actually, Cao incorporates a critique of the US media's misrepresentation of Vietnam and the Vietnamese. In the journal of the narrator's mother, the author creates a section that questions the media explicitly: "My daughter, like the American accustomed to hearing about the savagery of foreign lands, might expect much more drama from a life in a country back there. Where's the cruel mother-in-law, where's the rape, the floggings, the bandits and the cannibals, the savage dismemberments? She would ask" (Cao 191). As the mother questions the mainstream media representations of Vietnamese history and culture, she equally discusses the implication of such representations: "What she wants to see is a good exciting movie of adventure set in a foreign land where people are as capable of inflicting brutalities - as they are of enduring them" (Cao 191). Such a critique serves as a double move to reinforce the critique itself. On the one hand, the mother blames her own Vietnamese American daughter for sharing the Orientalist representation of Vietnam in American popular culture and society; but on the other, such blaming is also meant to affirm her daughter as an "authentic" American and in that sense to identify with the gaze of the general American readership.

Moreover, the interest in the domestic political process is also articulated through Cao's identification with the tradition of Asian American women's autobiography such as Maxine Hong Kingston's The Woman Warrior. As Quynh Nhu Le observes, the story between Mai and her mother Thanh "emulates a common theme in Asian American literature" (397). Michele Janette notes how Cao relates the Trung sisters to the woman warrior in Kingston's work: “blending a revision of Maxine Hong Kingston's The Woman Warrior with an invocation of Vietnam's most celebrated women warriors, the Trung sisters, Cao emphasizes her novel's lineage in the Asian American and Vietnamese cultural traditions" (60). Such a reframing and reconfiguration of Vietnamese women warriors suggests that Cao seeks to develop a new writing strategy and intends her work to be read in a discourse of US multiculturalism that celebrates diversity but never questions the power relationship that produces such a diversity. Like the narrator in Kingston's The Woman Warrior, who interrogates the tragedy of the no-name 


\section{SARE, Vol. 58, Issue 2 | 2021}

woman without unveiling the social and historical context in which it was produced, Cao glorifies Vietnamese resistance to the Chinese invasion in its ancient history but never directly describes Vietnamese resistance to US military intervention in Vietnam or the sufferings endured by the Vietnamese people during and after the American War in Vietnam.

What is most important is that Cao's work represents a new version of the "model minority" myth and a new willingness to participate in global capitalism. As Viet Thanh Nguyen observes, the authors of the "reconciliation narratives" address "American demands for a healing of their war wounds, a healing that assists the continuing movement of American capitalism and Vietnamese reconstruction, bringing to closure a deep crisis in American culture" $(2002,124)$. What Nguyen suggests here is that reconciliation narratives are directed toward the American "healing process" and the reconstruction of Vietnam, both of which would enable American and other transnational capital to flow back to Vietnam as a new site for labour and consumer consumption. History in an ironical sense becomes circular as Patricia Pelley notes of the mentality of the Vietnamese today:

Given the degree to which the interests of foreign capital govern Vietnam today, many Vietnamese are haunted by the thought that the horrendous loss of life and vast ecological damage they have endured over the past fifty years merely set the stage for what they are witnessing today: the reappearance of a wealthy capitalist elite, the reemergence of extraordinary poverty, and the reminder that the destiny of Vietnam is only partially controlled by the Vietnamese. (5)

As promised by the brochure of the college that her character of Mai has applied for, Cao emphasizes that every new student will have the openness of an unexplored future and the safety of its sanctuary that distinguishes itself as "a college for women, the challenge to excel" (260). After exploring the family history of Mai and the US intervention in Vietnam, Cao celebrates the character's new sense of confidence in the market of global capitalism: "I would follow the course of my own future. The acceptance letter from the Admissions Office whispered a starlight reassurance" (260). The author assures us that Mai will succeed in American culture and society.

In reading Cao's work in the context of the US-centered global order, which has now privileged the Asia Pacific more than ever before, I suggest why and how Empire as an important political and economic force has accommodated and transformed American cultural production during the late twentieth century. I also suggest that Asian American cultural production as part of American minority discourse and part of the global memory industry has not been exempt from the impact of Empire, which commodifies and neutralizes political resistance 


\section{SARE, Vol. 58, Issue 2 | 2021}

and cultural difference. In that sense, we should seriously engage the questions raised by Hardt and Negri on our political task with a difference: How should we understand changing US-Vietnam relations? Why would our critical reflection upon Empire matter?

\section{Notes}

${ }^{1}$ See the document: http://www.mofa.go.jp/region/n-america/us/security/security.html.

\section{Works Cited}

Bhabha, Homi K. “Of Mimicry and Man: The Ambivalence of Colonial Disourse," in The Location of Culture. . New York: Routledge, 1994.

Cao, Lan. Monkey Bridge. New York: Penguin, 1997.

Clinton, Hillary. “America’s Pacific Century.” Foreign Policy. 10/17/2011.

Dalton, Mathew. “Beyond Port Visits, US-Vietnam Relations Can Go Further,” The Diplomat. March $27,2020$. https://thediplomat.com/2020/03/beyond-port-visits-us-vietnam-relations-can-go-further/.

"Declaration of Independence of the Democratic Republic of Vietnam, September 2, 1945," from Vietnam: A History in Documents, ed. Gareth Porter. New York: New American Library, 1981.

Ettenheim, Susan Geller. "Crossing Bridges: Bookgrrl Interviews Lan Cao.” http://www.cybergrrl.com/fun/bookgrrl/art373/. 12/10/2002.

Fanon, Frantz. The Wretched of the Earth. New York: Grove Press, 1963.

Fukuyama, Francis. The End of History and the Last Man. New York: The Free Press, 1992.

Hardt, Michael and Antonio Negri, Empire. Cambridge, MA: Harvard University Press, 2000.

Hayslip, Le Ly. When Heaven and Earth Changed Places. New York: Plume, 1989.

Janette, Michelle. “Guerrilla Irony in Lan Cao’s Monkey Bridge,” Contemporary Literature 42:1 (2001). 


\section{SARE, Vol. 58, Issue 2 | 2021}

Kaplan, Amy. "Violent Belongings and the Question of Empire Today-Presidential Address to the American Studies Association, October 17, 2003,” American Quarterly, Vol. 56, No. 1 (March 2004).

Le, Quynh Nhu. "The Colonial Choreographies of Refugee Resettlement in Lan Cao's Monkey Bridge." Journal of Asian American Studies 21.3 (2018): 395-420.

Marx, Karl. "The Poverty of Philosophy," in The Marx-Engels Reader, ed. Robert C. Tucker. New York: Norton, 1978.

Nguyen, Viet Thanh. Race and Resistance: Literature and Politics in Asian America. New York: Oxford University Press, 2002.

---. Nothing Ever Dies: Vietnam and the Memory of War. Cambridge, Mass: Harvard University Press, 2016.

O’Driscoll, Bill. "Vietnamese-American Author Pushes For More Diverse Perspectives On The War," Pittsburg's NPR News Station, September 2, 2019.

https://www.wesa.fm/post/vietnamese-american-author-pushes-more-diverse-perspectives-war\#stream/0

Pelley, Patricia. Postcolonial Vietnam: New Histories of the National Past. Durham, NC: Duke UP, 2002.

Shih, Shu-mei. "Global Literature and the Technologies of Recognition,” PMLA, Vol. 119, No.1. (2004), 25.

Tram, Dang Thuy. Last Night I Dreamed of Peace. New York: Harmony Books, 2007.

Twining, Daniel. “America’s Grand Design in Asia.” The Washington Quarterly. 30.3 (2007). 